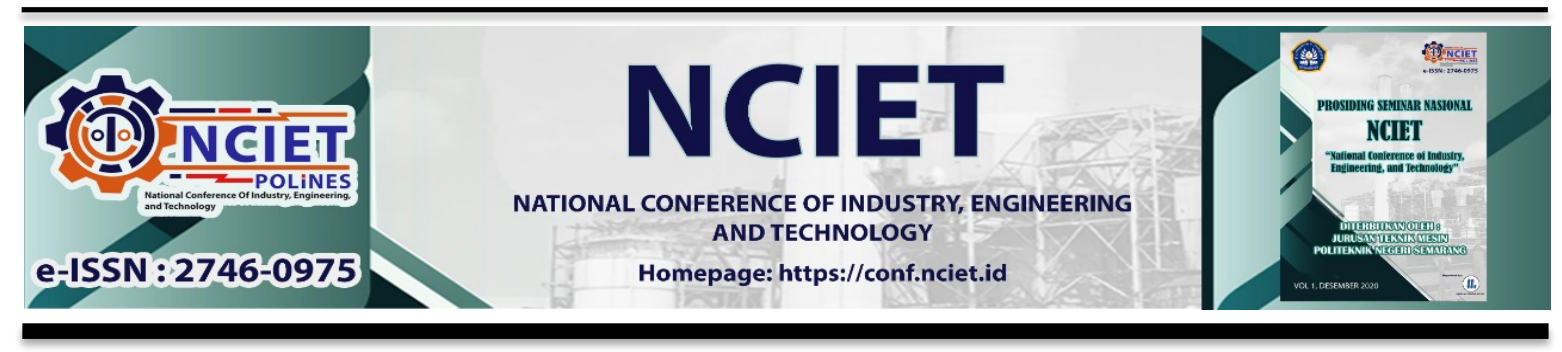

Prosiding Seminar Nasional NCIET Vol.1 (2020) B29-B35

$1^{\text {st }}$ National Conference of Industry, Engineering and Technology 2020,

Semarang, Indonesia.

\title{
ANALISIS KINERJA PEMANFAATAN TENAGA SURYA PADA AC SPLIT DENGAN REFRIJERAN R22
}

\author{
Yudhy Kurniawan*, Bobi Khoerun, Ghihar Fatihah \\ Teknik Pendingin dan Tata Udara, Politeknik Negeri Indramayu \\ J1. Raya Lohbener Lama No.8, Kec. Lohbener, Indramayu, 45252 \\ *E-mail:k.yudhy@yahoo.com
}

\begin{abstract}
Abstrak
Saat ini kebutuhan energi didunia masih didominasi bahan bakar fosil yang semakin menipis, dimana konsumsi terbesar yang dihasilkan dari fosil ini adalah energi listrik. Untuk kondisi negara tropis rata-rata setiap rumah maupun di gedung-gedung kota banyak menggunakan AC split sebagai alat untuk mengkondisikan ruangan agar terasa nyaman bagi penghuninya. Dimana sekitar $60 \%$ memanfaatkan energy listrik. Dalam penelitian ini AC split menggunakan tenaga surya sebagai alternatif energy listrik dengan menggunakan solar photovoltage (PV) system sebagai media penyerap sinar matahari untuk dikonversikan menjadi energy listrik pada AC split. Tujuannya agar pemanfaatan radiasi matahari mampu mereduksi penggunaan energy listrik dari PLN yang selama ini membutuhkan biaya yang besar. Metode penelitian diawali dengan membuat model alat yang dimodifikasi panel listrik pada AC split yang dihubungkan pada inverter untuk mengubah arus DC menjadi AC dari PV cell. Dari penggunaan solar cell sebagai energy listrik kemudian dibandingkan hasil pengujiannya dengan AC split konvensional. Hasil yang diperoleh dari pengujian AC split tenaga surya dapat diketahui efisiensi panel surya sebesar $8 \%$ dengan intensitas radiasi matahari tertinggi sebesar $1163,2 \mathrm{~W} / \mathrm{m}^{2}$ dan penghematan energy dapat beroperasi selama 2 jam perhari dengan daya $376 \mathrm{Wh}$.
\end{abstract}

Kata Kunci: Pemanfaatan Tenaga Surya; AC split; efisiensi; penghematan energi

\section{PENDAHULUAN}

Saat ini, alat pengkondisian udara (air conditioner /AC) sudah menjadi kebutuhan primer bagi sebagian besar penduduk diperkotaan sudah menjadi barang perabot umum pada rumah tangga di perkotaan. Alat pengkondisian udara banyak diperlukan karena Indonesia merupakan negara yang beriklim tropis dimana kondisi udara cenderung panas dan lembab, sehingga tidak nyaman untuk beraktivitas. Pengkondisi udara umumnya mengkonsumsi energi listrik untuk beroperasi yang besarnya tergantung dari kapasitas pendinginannya. Pada kondisi yang lain perlu disadari bahwa kebutuhan akan bahan bakar fosil semakin besar sementara ketersediaannya semakin menipis, sehingga jika tidak dilakukan inovasi tentang energy alternative akan mengancam generasi yang akan datang, dan untuk saat ini konsumsi 
terbesar sekitar 42,5\% ada pada total konsumsi listrik, sedangkan kebutuhan energy listrik terbesar ada pada penggunaan pengkondisian udara (AC split) (Yudhy, 2018). Dengan alasan ini pula menjadi perhatian penelitian terhadap pemanfaatan energy terbarukan seperti energy matahari sebagai energy listrik pada AC split yang diharapkan dapat menghemat biaya listrik. Pemanfaatan energi terbarukan diantaranya dengan memanfaatkan tenaga radiasi matahari dengan menggunakan sel surya sebagai pengkonversi energi matahari menjadi energi listrik, untuk pemanfaatan sumber energi alternatif (Arian, 2015).

Pada saat ini, lebih dari $10 \%$ energi listrik dikonsumsi dalam bentuk DC dan diperkirakan dimasa yang akan datang banyak peralatan elektronik menggunakan sumber arus DC (Taufik, 2015). Sedangkan pada Air Conditioning kerja kompresor menggunakan arus AC, sehingga dibutuhkan inverter untuk mengubah menjadi arus AC. Pada penelitian ini akan dilakukan analisis seberapa besar performansi dari system AC split yang dimodifikasi dengan tenaga surya, dibandingkan dengan AC split konvensional, serta seberapa besar penghematan biaya yang dihasilkan dari pemanfaatan energy matahari ini. Sehingga tujuan penelitian dapat menjadi referensi untuk pengembangan teknologi AC split dengan pemanfaatan energy alternative khususnya tenaga surya.

\section{METODE PENELITIAN}

Metode penelitian yang digunakan dalam penelitian ini adalah secara teoritis dan eksperimental. Metode secara teoritis menggunakan parameter rancangan dari system AC split yang sudah dimodifikasi dengan system solar cell, sedangkan metode secara eksperimental dilakukan setelah prototype alat beroperasi dengan baik kemudian dilakukan pengujian untuk mengetahui perbandingan analisis performansi system AC split yang sudah dimodifikasi tersebut dengan AC split konvensional. Skema rancangan system dapat dilihat pada Gambar 2. Tahapan-tahapan penelitian yang akan dilakukan dapat dilihat pada diagram alir (flowchart) penelitian berikut: 


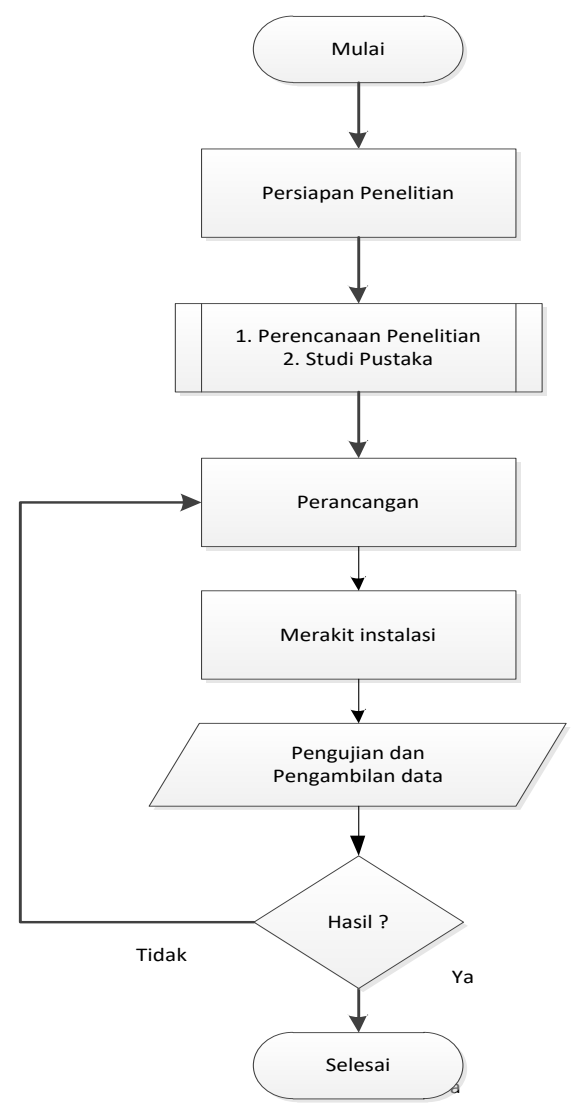

Gambar 1. Diagram alir penelitian

\section{Tahapan Persiapan}

Studi pustaka dilakukan untuk mendapatkan materi mengenai pendahuluan, tinjauan pustaka, data-data atau informasi sebagai bahan acuan dalam melakukan pengujian. Perencanaan dilakukan agar tidak terjadi banyak kesalahan pada saat proses pembuatan alat.

\section{Tahapan Perancangan}

Tahapan ini merupakan tahapan awal mendesain sistem yang akan kita buat. Dalam tahapan ini data rancangan awal sistem yang dibuat. Perancangan desain solar cell, kemudian system instalasi dari AC split yang dihubungkan dengan Photovoltaic (PV) system. Setelah itu memilih material dan komponen yang akan digunakan sesuai perhitungan rancangan yang dihasilkan.

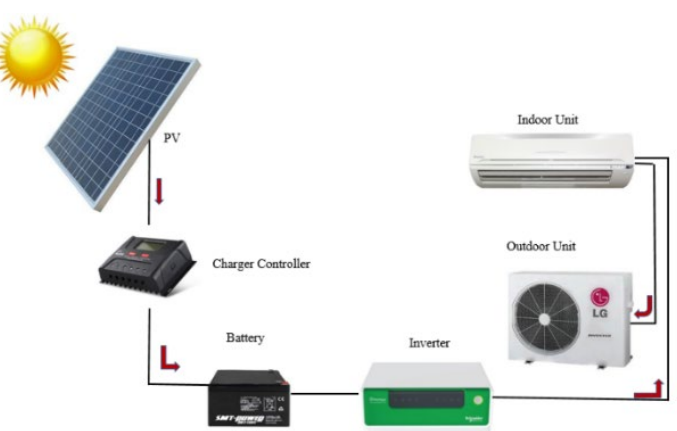

Gambar 2. Skema rancangan AC split tenaga surya 


\section{Tahapan Pembuatan Prototipe}

Setelah desain rancangan selesai dibuat, selanjutnya membuat prototype AC split tenaga surya. Untuk AC split ini menggunakan refrigerant R22. Kemudian menambahkan beberapa alat yang diperlukan sebagai pelengkap dari instalasi PV modul dan AC split seperti inverter, battery, charge controller. Dalam pembuatan instalasi ini perlu disesuaikan pemilihan alatalat berdasarkan perancangan yang sudah dilakukan.

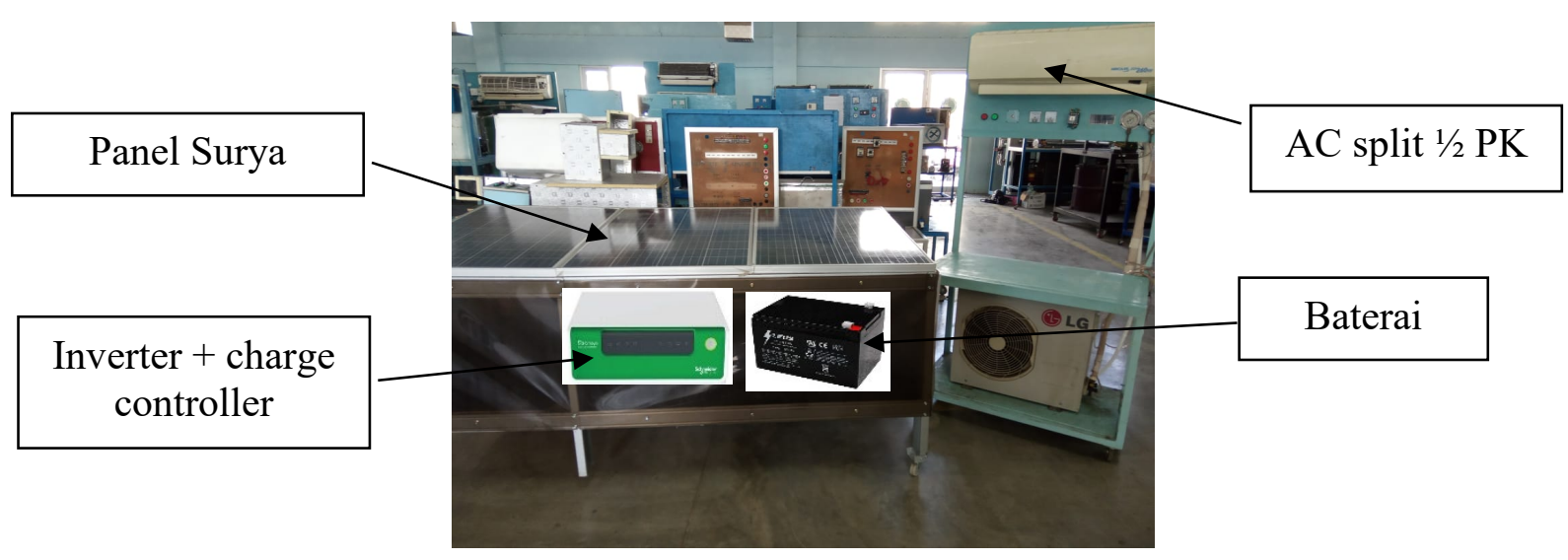

Gambar 4. Sistem AC split tenaga surya

\section{Tahapan Pengujian dan Pengambilan Data}

Pengujian terhadap system dilakukan setelah proses pembuatan dan instalasi system selesai, dimana pengujian ini dilakukan untuk mengetahui apakah beroperasi dengan baik atau tidak. Jika alat tidak berfungsi sebagaimana mestinya maka dilakukan analisa untuk memperbaiki kekurangan dari alat tersebut agar dapat berfungsi dengan baik. Setelah dipastikan system berjalan dengan baik, kemudian tahapan selanjutnya adalah melakukan pengambilan data, pada tahap ini akan diambil beberapa data dengan menggunakan alat ukur seperti: solar power meter, volt meter, tang ampere, stopwatch, power meter. Pengambilan data dilakukan selama 2 hari, dengan waktu pengambilan data selama 8 jam dengan rentang 10 menit sekali pada system AC tenaga surya, maupun konvensional. Data yang diambil diantaranya intensitas cahaya matahari, tegangan keluaran solar panel, arus keluaran solar panel.

\section{HASIL DAN PEMBAHASAN}

Pengambilan data dilakukan pada saat system AC split tenaga surya beroperasi, dimana dilakukan selama 2 hari dengan durasi pengambilan data selama 12 jam pada rentang 1 jam sekali, sehingga hasil penyerapan radiasi matahari selama 12 jam yang diperoleh cukup untuk mengoperasikan AC split selama 2 jam. 


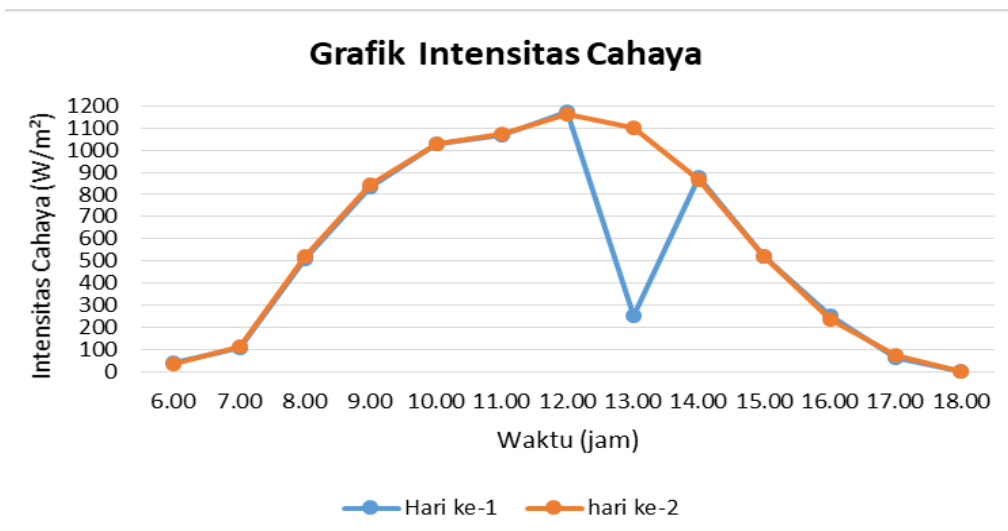

Gambar 5. Grafik Intensitas Cahaya terhadap waktu

Dari grafik pengelompokan hasil pengukuran intensitas cahaya selama 2 hari diatas, menunjukan intensitas tertinggi terjadi pada pukul 12.00 hari ke-1 yaitu mencapai 1174,8 $\mathrm{W} / \mathrm{m}^{2}$. Pada siang hari sekitar pukul 13.00 sampai 17.00 terus mengalami peningkatan dan penurunan intensitas matahari yang rata tingginya pada hari ke-1 dan ke-2 mengalami perbedaan dikarenakan pada saat itu kondisi cuaca sekitar sedang berawan yang mengakibatkan intensitas mengalami penurunan, karena suhu dan cuaca lingkungan sekitar sangat berpengaruh pada efektifitas panel surya.

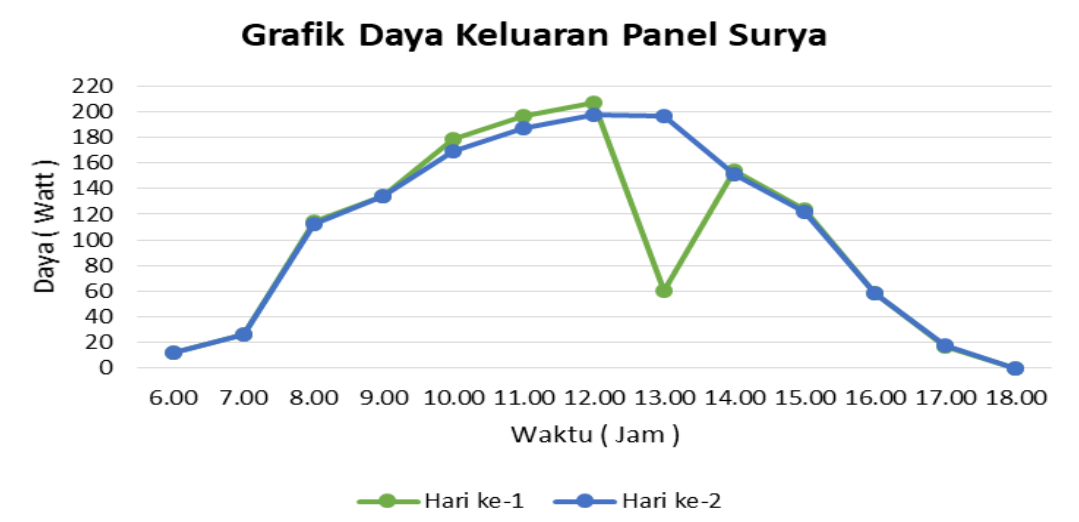

Gambar 6. Grafik Daya Keluaran Panel terhadap waktu

Dari grafik pengelompokan hasil daya keluaran panel selama 2 hari diatas, menunjukan daya yang di peroleh paling tinggi terdapat pada pukul 12.00 hari ke-1 yaitu mencapai 206,57 watt, karena semakin tinggi intensitas cahaya yang diserap oleh panel maka daya yang dihasilkanpun semakin besar yang akan di supply ke battery, begitupun sebaliknya semakin rendah intensitas yang diserap panel maka daya yang dihasilkan akan semakin kecil untuk di supply ke battery. 
1. Perhitungan efisiensi panel surya

Untuk perhitungan efisiensi panel surya, mengambil sampel pada intensitas radiasi matahari tertinggi yaitu pada pukul 12.00 hari ke-1 sebesar $1174,8 \mathrm{~W} / \mathrm{m}^{2}$, menghasilkan daya keluaran sebesar 206,57 Watt. Sehingga nilai efisiensi panel surya yang didapat adalah sebagai berikut:

$$
\begin{aligned}
& \text { Efisiensi Panel Surya }(\eta)=\frac{\text { daya keluaran }}{\text { intensitas radiasi }} \times 100 \% \\
& =\frac{206,57 \text { watt }}{1174,8 \frac{W}{m^{2}} \times 2 \mathrm{~m}^{2}} \times 100 \%=9 \%
\end{aligned}
$$

\begin{tabular}{|c|c|c|c|c|c|c|c|c|c|c|c|c|c|}
\hline Hari & 06.00 & 07.00 & 08.00 & 09.00 & 10.00 & 11.00 & $\begin{array}{c}\mathrm{Jam} \\
12.00\end{array}$ & 13.00 & 14.00 & 15.00 & 16.00 & 17.00 & 18.00 \\
\hline 1 & $15 \%$ & $12 \%$ & $11 \%$ & $8 \%$ & $8 \%$ & $9 \%$ & $9 \%$ & $12 \%$ & $9 \%$ & $12 \%$ & $12 \%$ & $14 \%$ & $0 \%$ \\
\hline 2 & $16 \%$ & $11 \%$ & $11 \%$ & $8 \%$ & $8 \%$ & $9 \%$ & $8 \%$ & $9 \%$ & $9 \%$ & $12 \%$ & $12 \%$ & $12 \%$ & $0 \%$ \\
\hline
\end{tabular}

Tabel 1. Perhitungan Efisiensi Panel Surya

Dari tabel efisiensi panel selama 2 hari diatas, menunjukan efisiensi panel paling tinggi terdapat pada pukul 6.00 hari ke-2 yaitu mencapai $16 \%$, karena intensitas cahaya pada pukul tersebut cukup kecil dan daya keluaran yang dihasilkanpun kecil sehingga menghasilkan efisiensi paling tinggi. Efisiensi pada panel surya itu berbanding terbalik dengan intensitas dan daya, Oleh karena itu ketika intesitas matahari semakin besar maka daya yang dihasilkanpun semakin besar sehingga mempengaruhi efisiensi yang dihasilkan pada panel tersebut. Efisiensi juga dipengaruhi oleh temperature sekitar, panel surya dirancang memiliki STC (Standar Test Condition) yaitu $25^{\circ} \mathrm{C}$ oleh karena itu ketika temperatur mengalami kenaikan lebih dari $25^{\circ} \mathrm{C}$ akan berkurang $0,5 \%$ efisiensi pada panel tersebut.

2. Perhitungan daya dan estimasi penghematan AC split tenaga Surya

Untuk pemakaian AC Split biasanya konsumsi daya tergantung dari daya AC Split yang dinyalakan selama 2 jam sehingga untuk menghitung daya yang di pakai adalah :

$\mathrm{P}=\mathrm{V} \times \mathrm{I} \times \operatorname{Cos} \mu$

Diketahui : $\quad \mathrm{V}=196$ Volt

$\mathrm{I}=1,2$ Ampere

$\operatorname{Cos} \mu=0,8$

Sehingga diperoleh daya $(\mathrm{P})$ sebesar 188,16 watt

Konsumsi Pemakaian per hari : ( P/1000 ) x waktu pemakaian selama 2 jam

Diperoleh penghematan daya perhari sebesar $0.376 \mathrm{kWh}$ 


\section{KESIMPULAN}

Berdasarkan hasil pengujian dan analisa pembahasan, dapat disimpulkan sebagai berikut:

1. Dari hasil pengujian alat yang telah dilakukan, dengan menggunakan sistem pembangkit listrik tenaga surya yang telah dirancang sebagai sumber untuk mengoperasikan AC split yang terdiri dari 3 buah panel surya $100 \mathrm{WP}$ disusun secara pararel, 2 buah baterai kapasitas 145 Ah dan inverter 850 VA. Sehingga diketahui bahwa AC split tenaga surya dapat beroperasi selama 2 jam.

2. Efisiensi panel surya diperoleh nilai tertinggi pada hari ke-2 pukul 06.00 mencapai $16 \%$, sedangkan pada pukul 12.00 dimana mendapat intensitas radiasi tertinggi namun nilai efisiensi panel suryanya rendah sebesar $8 \%$, hal ini karena efisiensi panel berbanding terbalik terhadap intensitas radiasi matahari. Selain itu efisiensi juga dipengaruhi oleh temperature sekitar, panel surya dirancang memiliki STC (Standar Test Condition) yaitu $25^{\circ} \mathrm{C}$ oleh karena itu ketika temperatur mengalami kenaikan lebih dari $25^{\circ} \mathrm{C}$ akan berkurang $0,5 \%$ efisiensi pada panel tersebut.

3. Dari hasil analisis penggunaan daya listrik untuk AC split tenaga surya dan estimasi penghematan biaya untuk pengoperasian selama 2 jam perhari membutuhkan daya listrik sebesar $0,376 \mathrm{kWh}$.

Untuk saran pengembangan pada penelitian lanjutan dapat diperhitungkan beban pendinginan dan perbandingan efisiensi system pendingin pada $\mathrm{AC}$ split tersebut dengan penggunaan energy listrik dari PLN.

\section{DAFTAR PUSTAKA}

Yudhy, K. (2018). Prototipe Sistem Hibrid-Pemanfaatan Panas AC Split dan Radiasi Panas Matahari Untuk Pemanas Air. Prosiding Seminar Nasional Penelitian dan Pengabdian pada Masyarakat, hal. 190, ISBN: 978-602-61545-0-7.

Arian, D. P., Nasrun, H., \& Syahrial. (2015). Perancangan Modifikasi Air Conditioner dan Penerapan PLTS sebagai Sumber Catu Daya. Jurnal Reka Elkomika, ITENAS, hal. 42

Taufik, I. A. R., Nasrun, H., \& Waluyo. (2015). Perancangan dan Realisasi Alat Penetas Telur Dengan Catu Daya Pembangkit Listrik Tenaga Surya Berbasis Arduino Uno R3, Jurnal Reka Elkomika 2337-439X, Vol. 3, No. 1, Institut Teknologi Nasional 